\title{
In vitro rhizogenesis and acclimatization of Peltophorum dubium shoots: effect of adding agar to a WPM/2 medium with vermiculite
}

\author{
Rizogênese e aclimatização in vitro de brotações de canafístula: \\ efeito do ágar em meio WPM/2 com vermiculita
}

\author{
Lia Rejane Silveira Reiniger ${ }^{1}$, Aline Ritter Curti², Diego Pascoal Golle ${ }^{3}$, \\ Aline Ferreira Paim ${ }^{4}$ e Marlove Fátima Brião Muniz ${ }^{5}$
}

\begin{abstract}
Resumo
A canafístula [Peltophorum dubium (Sprengel) Taubert] é uma espécie florestal nativa do Brasil dotada de importância ecológica e econômica. Os estudos preliminares sobre a micropropagação da espécie abordaram aspectos do estabelecimento e da multiplicação in vitro e indicaram que a espécie apresenta potencial para essa técnica de propagação assexuada. Em decorrência disso, o presente estudo teve como objetivo avaliar a rizogênese in vitro em brotações de canafístula via micropropagação em diferentes meios de cultivo contendo variações nas concentrações de auxina, sacarose e de ágar, bem como analisar a subsequente aclimatização in vitro das mudas produzidas. A rizogênese foi avaliada em diferentes meios de cultivo, os quais continham $30 \mathrm{~cm}^{3}$ de vermiculita combinados ao meio nutritivo WPM/2 e alterações nas concentrações de sacarose $\left(0,15\right.$ ou $\left.30 \mathrm{~g} \mathrm{~L}^{-1}\right)$, presença ou ausência de ágar $\left(0\right.$ ou $\left.7 \mathrm{~g} \mathrm{~L}^{-1}\right)$ e de ácido 3-indolbutírico - AIB (0 ou $10 \mu \mathrm{M}$ ), conforme o tratamento. Brotações enraizadas foram transferidas para substrato e submetidas à aclimatização in vitro. Os resultados indicaram que a melhor combinação tanto para a rizogênese (média de 44,43\%) quanto para a aclimatização in vitro é aquela que inclui $7 \mathrm{~g} \mathrm{~L}^{-1}$ de ágar ao meio nutritivo WPM/2, dispensando-se a sacarose e a auxina. Melhor qualidade do sistema radicular em brotações micropropagadas de canafístula e satisfatória sobrevivência das plantas obtidas na aclimatização in vitro provêm do uso de ágar no meio nutritivo WPM/2, combinado com $30 \mathrm{~cm}^{3}$ de vermiculita, na ausência de sacarose e de AIB.
\end{abstract}

Palavras-chave: Espécie florestal; cultura de tecidos; micropropagação.

\begin{abstract}
Peltophorum dubium (Sprengel) Taubert is a forest tree that is native to Brazil and that has ecological and economic importance. Preliminary studies on the micropropagation of the species covered aspects of the in vitro establishment and multiplication and indicated that it has potential for this type of asexual propagation. The present study evaluated the in vitro rhizogenesis of $P$. dubium shoots via micropropagation on different culture media with different concentrations of sucrose, auxin, and agar and analyzed the subsequent in vitro acclimatization of the plantlets. Rhizogenesis was evaluated on half-strength Woody Plant Medium nutritive medium that contained $30 \mathrm{~cm}^{3}$ vermiculite and different concentrations of sucrose $\left(0,15\right.$, or $30 \mathrm{~g} \cdot \mathrm{L}^{-}$ $\left.{ }^{1}\right)$, the auxin indole-3-butyric acid $(0$ or $10 \mu \mathrm{M})$, and agar $\left(0\right.$ or $\left.7 \mathrm{~g}^{\cdot \mathrm{L}^{-1}}\right)$. Rooting shoots were transferred to a substrate for in vitro acclimatization. The best medium both for rhizogenesis (producing roots in $44.43 \%$ of cases); and for in vitro acclimatization contained $7 \mathrm{~g} \cdot \mathrm{L}^{-1}$ agar but no sucrose or auxin. The addition of agar to the medium in the absence of sucrose and indole-3-butyric acid resulted in a better quality radicular system in micropropagated shoots of $P$. dubium and with a satisfactory survival rate of the plantlets during in vitro acclimatization.
\end{abstract}

Keywords: forest species; tissue culture, micropropagation.

\footnotetext{
1Professora associada do Departamento de Fitotecnia. UFSM - Universidade Federal de Santa Maria. Campus Universitário - Camobi - 97105900 - Santa Maria, RS, Brasil. E-mail: liarsr@ufsm.br.

${ }^{2}$ Doutora em Engenharia Florestal. UFPel - Universidade Federal de Pelotas, Faculdade de Agronomia Eliseu Maciel. Campus Universitário - 96160000 - Capão do Leão, RS, Brasil. E-mail: alinerittercurti@yahoo.com.br.

3Professor Adjunto. Unicruz - Universidade de Cruz Alta / Pró-Reitoria de Pós-Graduação, Pesquisa e Extensão. Campus Universitário Dr. Ulysses Guimarães. Rodovia Municipal Jacob Della Méa, km 5,6 - Prédio 4, Pró-Reitorias - Parada Benito - 98020290 - Cruz Alta, RS - Brasil. E-mail: diego.golle@gmail.com.

${ }^{4}$ Doutora em Engenharia Florestal. UFSM - Universidade Federal de Santa Maria. Campus Universitário - Camobi 97105900 - Santa Maria, RS, Brasil. E-mail: alinepaimal@yahoo.com.br.

${ }^{5}$ Professora Titular do Departamento de Defesa Fitossanitária. UFSM - Universidade Federal de Santa Maria. Campus Universitário - Camobi - 97105900 - Santa Maria, RS, Brasil. E-mail: marlovemuniz@yahoo.com.br.
}

Sci. For., Piracicaba, v. 44, n. 111, p. 691-700, set. 2016 DOI: dx.doi.org/10.18671/scifor.v44n111.15 


\section{INTRODUCTION}

Little technical information is available on the production of plantlets of native species in Brazil, hindering advances in the silviculture of these species (OLIVEIRA et al., 2013). The quality of the plantlets used in commercial plantations affects the subsequent growth of the trees and the ultimate success of programs for forestry development, so producing better quality plantlets would improve forestry productivity (XAVIER et al., 2013).

One native species of Brazil that is of economic interest and about which little is known is Peltophorum dubium (Sprengel) Taubert] (Fabaceae), commonly known as "canafístula," also known in different regions of Brazil as "acácia amarela," "barbatimão," and "angico-bravo," among other names. This tree is recommended for reforestation projects in riparian forests and for the rehabilitation of degraded areas, and its wood, both sawn and round, has high value due to its moderate resistance to rotting (LORENZI, 1992; SILVA et al., 2008). The literature on the production of seedlings of this species mainly deals with sexual reproduction (PEREZ et al., 1999; PORTELA et al., 2001; POLETTO et al., 2007; BRACHTVOGEL; MALAVASI, 2010; NAKAGAWA et al., 2010).

The first studies on the micropropagation of $P$. dubium focused on aspects of in vitro establishment and multiplication (BASSAN et al., 2006; CURTI et al., 2010a; CURTI et al., 2010b; FLÔRES et al., 2011). They indicated that the species is suitable for asexual propagation but also identified a need for additional studies on in vitro multiplication and rhizogenesis.

Our group has already been able to obtain an average of $36.78 \%$ in vitro root formation in shoots cultivated for 60 days on a culture medium containing fine-grained vermiculite and agar, as well as when using the nutrititive medium MS (MURASHIGE; SKOOG, 1962) supplemented with $10 \mu \mathrm{M}$ of the auxin indole-3-butyric acid (IBA) (CURTI; REINIGER, 2014). After that, our group optimized the ratio of in vitro root formation, resulting in an average $36.30 \%$ rhizogenesis when the shoots were cultivated for only 30 days on Woody Plant Medium (WPM) (LLOYD; MCCOWN, 1980), using half the standard salt concentration (WPM/2), agar, fine-grained vermiculite, $30 \mathrm{~g} \cdot \mathrm{L}^{-1}$ sucrose, 10 $\mu \mathrm{M}$ IBA, and $50 \mathrm{mg} \cdot \mathrm{L}^{-1}$ myoinositol (data not published).

Considering the results obtained to date, the objective of this work was to increase that average ratio by evaluating the in vitro rhizogenesis of $P$. dubium shoots using micropropagation on distinct culture media with different concentrations of sucrose, auxin, and agar, as well as to analyze the subsequent in vitro acclimatization of the plantlets.

\section{MATERIAL AND METHODS}

Both the rhizogenesis and the in vitro acclimatization assays were carried out according to an entirely randomized design. The tests were conducted at the Núcleo de Biotecnologia e Melhoramento, Universidade Federal de Santa Maria, Rio Grande do Sul, Brazil.

In order to evaluate rhizogenesis, a trifactorial scheme $(3 \times 2 \times 2)$ that varied sucrose concentrations $\left(0,15\right.$, or $\left.30 \mathrm{~g} \cdot \mathrm{L}^{-1}\right)$, IBA $(0$ or $10 \mu \mathrm{M})$, and agar $\left(0\right.$ or $\left.7 \mathrm{~g} \cdot \mathrm{L}^{-1}\right)$ in the nutritive medium was employed. We used as explants shoots that were micropropagated for 60 days on MS, in the absence of growth regulators.

Each experimental unit consisted of a $150 \mathrm{~mL}$ glass flask filled with $30 \mathrm{~mL}$ half-strength WPM, $30 \mathrm{~cm}^{3}$ vermiculite, and three shoots. The combination of WPM/2 with vermiculite is henceforth referred to as culture medium. Six replications per treatment were used.

WPM/2 nutritive medium was supplemented with $50 \mathrm{mg} \cdot \mathrm{L}^{-1}$ myoinositol, as well as sucrose and IBA, where applicable. The $\mathrm{pH}$ was adjusted to 5.8 before agar was added (for the treatments in which agar was used), before autoclaving at $121^{\circ} \mathrm{C}$ and at 1 atm for $15 \mathrm{~min}$.

The flasks were covered with aluminum foil and kept in a growth room at $25 \pm 3{ }^{\circ} \mathrm{C}$, with a photoperiod of $16 \mathrm{~h}$, and $20 \mu \mathrm{mol} \cdot \mathrm{m}^{-2} \cdot \mathrm{s}^{-1}$ light intensity from white fluorescent lamps. These growing conditions have been used on in vitro rhizogenesis assays with this species (CURTI; REINIGER, 2014) and have generated satisfactory results.

After 60 days of cultivation, survival rates (\%), shoots with root formation (\%), number of roots, root lengths $(\mathrm{cm})$, shoots with secondary roots (\%), shoots with basal callus (\%), number of leaves per explant, and leaves with symptoms of senescence (\%) were evaluated. Senescence was defined as the yellowing of leaves and/or presence of dry edges. 
In the in vitro acclimatization assay, we used a bifactorial scheme $(12 \times 8)$. The 12 levels from factor " $\mathrm{A}$ " consisted of combinations of sucrose $\left(0,15\right.$, or $\left.30 \mathrm{~g} \cdot \mathrm{L}^{-1}\right)$, IBA $(0$ or $10 \mu \mathrm{M})$ and agar $(0$ or $7 \mathrm{~g} \cdot \mathrm{L}^{-1}$ ) and the eight levels from factor " $\mathrm{B}$ " were eight different cultivation times (for a total of eight weeks or 56 days).

The levels from factor " $\mathrm{A}$ " were the same used during the in vitro rhizogenesis assay (as described), from which the plantlets originated. Among the total number of shoots that formed roots those which had secondary roots were selected. We used at least three plantlets from each treatment that had formed adventitious roots after 60 days of cultivation, except in the treatment that used 30 $\mathrm{g} \cdot \mathrm{L}^{-1}$ of sucrose and $10 \mu \mathrm{M}$ IBA, because this treatment produced only two plantlets with roots, and both were used.

The plantlets were transferred in the flow table, after rinsing the roots, to transparent plastic cups (Figure 1), with a hole in bottom and a volume capacity of $180 \mathrm{~mL}$. Each cup was filled with 60 $\mathrm{mL}$ substrate (a mixture of vermiculite and commercial substrate, made of pine bark to which was added a corrective for soil acidity, mineral fertilizer, in the ratio $1: 1 ; \mathrm{v} / \mathrm{v}$ ), supplemented with $15 \mathrm{~mL}$ $\mathrm{WPM} / 2$ nutritive medium and $10 \mathrm{~mL}$ distilled water.

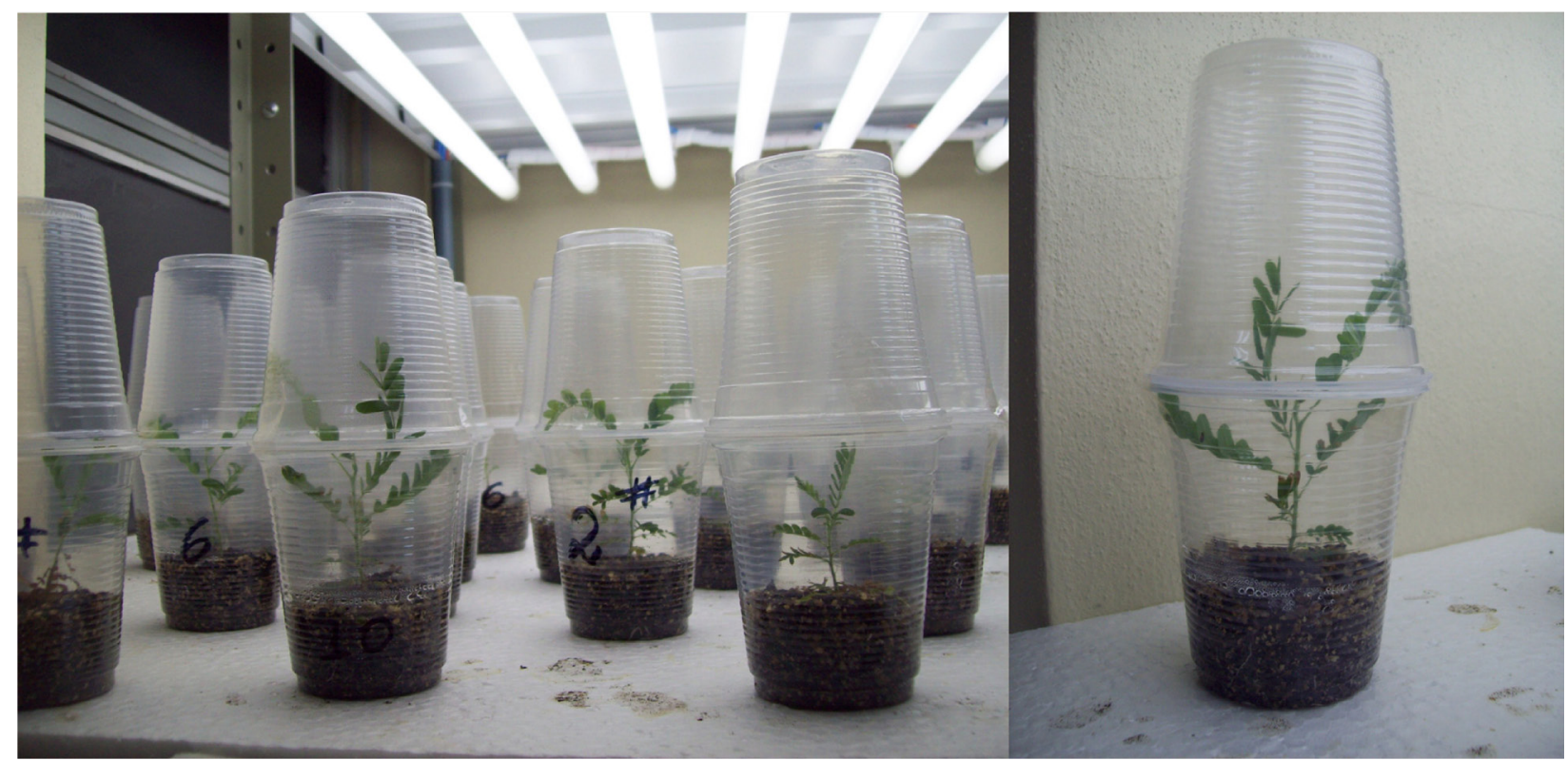

Figure 1. 1A - Micropropagated seedlings of Peltophorum dubium (Sprengel) Taubert at the end (60 days) of the in vitro acclimatization assay. $1 \mathrm{~B}$ - Each one (one experimental unity) was cultivated in transparent plastic cup (capacity of $180 \mathrm{~mL}$ filled with $60 \mathrm{~mL}$ substrate) covered by a second plastic cup with same capacity.

Figura 1. $1 \mathrm{~A}$ - Mudas micropropagadas de Peltophorum dubium (Sprengel) Taubert no final do ensaio de aclimatização in vitro (60 dias). 1B - Cada unidade experimental foi cultivada em copo plástico transparente (capacidade para $180 \mathrm{~mL}$ preenchidos com $60 \mathrm{~mL}$ de substrato) coberto por um segundo copo plástico de igual capacidade.

Each experimental unit was a single plastic cup containing one plantlet due to the cup size and in order to simultaneously promote the survival, establishment and encourage appropriate development of plants under the new condition. Each cup was covered with a second plastic cup (Fig. 1) that also had a hole punched in the bottom in order to retain humidity and at the same time enable gas exchange.

The humidity inside the cups was verified daily by visual observation of the appearance of the substrate if there was moisture or not and, when necessary, $10 \mathrm{~mL}$ distilled water was added in order to maintain the turgor of the plantlets. The plantlets were evaluated for survival (\%), number of leaves, and number of senescent leaves.

After testing the normality using the Kolmogorov-Smirnov test and the variance homogeneity using the Bartlett test, the variables were transformed, when required, using the $\sqrt{x+0,5}$ function, where $\mathrm{x}$ corresponds to the observed value. Analyses of variance were performed, and, when the F value was significant, the Scott-Knott test was used for the comparison between averages, at 5\% significance, for qualitative treatments, and polynomial regression was used for the quantitative analyses. 
Analyses of variance were performed with SISVAR (System for the Analyses of Variance) software for Windows ${ }^{\circledR}$, version 4.0 (FERREIRA, 2000). The precision of the experiment was assessed by selective accuracy (SA), calculated with the formula $\sqrt{1-1 / \text { Fcal }}$ (REZENDE; DUARTE, 2007).

\section{RESULTS AND DISCUSSION}

\section{In vitro rhizogenesis}

Among the various additions to the media, only IBA had a significant effect on the survival rate of shoots $(p=0.0393)$, the formation of calli for roots $(p=0.000)$, and the number of leaves per explant $((p=0.0028)$. The averages for these three measures were more favorable in the absence of IBA (Table 1).

It is important to clarify that the observed callus genesis did not compromise the development of the shoots. The formation of secondary roots was always preceded by calli formation and did not affect rhizogenesis.

Shoot development was also not compromised during micropropagation of Arabidopsis thaliana, where IBA concentrations up to $10 \mu \mathrm{M}$ induced the formation of secondary roots (in up to $95 \%$ of the shoots) (LUDWIG-MULLER et al., 2005). However, in contrast with the results of the present work, no calluses or secondary roots were observed in the absence of auxin (LUDWIG-MULLER et al., 2005).

Table 1. Mean values for shoots of Peltophorum dubium (Sprengel) Taubert, after 60 days of in vitro cultivation on half-strength Woody Plant Medium (WPM/2) supplemented with $30 \mathrm{~cm}^{3}$ vermiculite, for the following variables: A) survival (\%), calli formation (\%), and number of leaves per explant, according to the presence or absence of indole-3-butyric acid (IBA) $(0$ or $10 \mu \mathrm{M})$, regardless of sucrose concentration $(0,15$, or 30 $\left.\mathrm{g} \cdot \mathrm{L}^{-1}\right)$ or presence or absence of agar $\left(0\right.$ or $\left.7 \mathrm{~g} \cdot \mathrm{L}^{-1}\right) ; B$ ) formation of primary and secondary roots $(\%)$, according to agar addition, regardless of sucrose and IBA concentrations; and C) formation of secondary roots (\%) and leaves with senescence symptoms (\%), according to the concentration of sucrose, regardless of agar and IBA.

Tabela 1. Médias, em brotações de canafístula [Peltophorum dubium (Sprengel) Taubert], aos 60 dias de cultivo in vitro, em meio nutritivo 'Wood Plant Medium' (WPM) cuja concentração de sais foi reduzida à metade (WPM/2), acrescido de $30 \mathrm{~cm}^{3}$ de vermiculita, em: A) de sobrevivência (\%), formação de calos (\%) e número de folhas por explante, em função da ausência ou presença de ácido 3 -indolbutírico (AIB) (0 ou $10 \mu \mathrm{M})$, independentemente das concentrações de sacarose $\left(0 ; 15\right.$ ou $\left.30 \mathrm{~g} \mathrm{~L}^{-1}\right)$ e da ausência ou presença de ágar (0 ou $\left.7 \mathrm{~g} \mathrm{~L}^{-1}\right)$; B) de formação de raízes (\%) e de raízes secundárias (\%), em função do ágar, independentemente da sacarose e do AIB; e C) de formação de raízes secundárias (\%) e de folhas com sinais de senescência (\%), em função da sacarose, independentemente do ágar e do AIB.

\begin{tabular}{lccc}
\hline AlB $(\boldsymbol{\mu M})$ & Survival $(\%)$ & Calli (\%) & Number of leaves per explant \\
\hline 0 & $90.67 \mathrm{a}^{*}$ & $33.94 \mathrm{a}$ & $4.57 \mathrm{a}$ \\
10 & $75.29 \mathrm{~b}$ & $65.41 \mathrm{~b}$ & $3.31 \mathrm{~b}$ \\
Mean & 83.20 & 49.23 & 3.96 \\
$\mathrm{SA}^{* *}$ & 0.88 & 0.97 & 0.95 \\
\hline Agar $\left(\mathbf{g ~ L}^{-1}\right)$ & Formation of primary roots (\%) & Formation of secondary roots (\%) \\
\hline 0 & $28,30 \mathrm{~b}$ & $12,26 \mathrm{~b}$ \\
7 & $44,43 \mathrm{a}$ & $27,40 \mathrm{a}$ \\
Mean & 36,36 & 19,80 \\
SA & 0,90 & 0,96 \\
\hline Sucrose (g L-1) & Formation of secondary roots (\%) & Leaves with senescence (\%) \\
\hline 0 & $38.36 \mathrm{a}$ & $22.88 \mathrm{~b}$ \\
15 & $11.00 \mathrm{~b}$ & $23.63 \mathrm{~b}$ \\
30 & $8.25 \mathrm{~b}$ & $14.22 \mathrm{a}$ \\
Mean & 19.80 & 20.14 \\
SA & 0.96 & 0.81 \\
\hline
\end{tabular}

* Means followed by different lowercase letters in a column significantly differ from one another according to the Scott-Knott test, at $5 \%$ significance. The letter "a" refers to the best result. ** $S A$ (Selective Accuracy) $=\sqrt{1-(1 / F C)}$, where $\mathrm{Fc}=$ calculated $\mathrm{F}$ value. $\mathrm{SA} \geq 0.9=$ very high; SA between 0.7 and $0.9=$ high; SA between 0.5 and $0.7=$ moderate; and $S A \leq 0.5=$ low.

The presence of agar had a significant effect on root formation $(p=0.0254)$ and the presence of secondary roots $(p=0.000)$, resulting in satisfactory averages (Table 1$)$. However, unlike in primary root formation, the emergence of secondary roots was also significantly affected by sucrose. 
The average appearance of secondary roots without sucrose was more than three times as high as that observed in the presence of a carbohydrate source (Table 1). The absence of an external carbon source may have stimulated the cells to develop mechanisms to supply their nutritional requirements, culminating with the formation of secondary roots, which assist in the assimilation of nutrients by the primary roots.

Table 2. Mean root lengths ( $\mathrm{cm}$ ) of Peltophorum dubium (Sprengel) Taubert shoots after 60 days of cultivation on half-strength Woody Plant Medium (WPM/2) to which was added $30 \mathrm{~cm}^{3}$ vermiculite, according to the interaction between sucrose and IBA concentrations, regardless of the presence or absence of agar.

Tabela 2. Médias de comprimento médio de raízes $(\mathrm{cm})$, em brotações de canafístula [Peltophorum dubium (Sprengel) Taubert], aos 60 dias de cultivo in vitro, em meio nutritivo 'Wood Plant Medium' (WPM) cuja concentração de sais foi reduzida à metade (WPM/2), acrescido de $30 \mathrm{~cm}^{3}$ de vermiculita, em função da interação entre a sacarose e o AIB, independentemente da presença ou ausência de ágar.

\begin{tabular}{|c|c|c|c|}
\hline \multirow{2}{*}{ Sucrose $\left(\mathrm{g} \mathrm{L}^{-1}\right)$} & \multicolumn{2}{|c|}{ IBA $(\mu \mathrm{M})$} & \multirow[b]{2}{*}{ Mean } \\
\hline & 0 & 10 & \\
\hline 0 & $3.78 \mathrm{aA}$ & $0.81 \mathrm{bB}$ & 2.36 \\
\hline 15 & $1.11 \mathrm{bA}$ & $3.00 \mathrm{aA}$ & 2.01 \\
\hline 30 & $1.66 \mathrm{bA}$ & $0.41 \mathrm{bA}$ & 1.03 \\
\hline Mean & 2.26 & 1.31 & 1.80 \\
\hline$S A^{* *}$ & \multicolumn{2}{|c|}{0,90} & \\
\hline
\end{tabular}

* Means followed by different lowercase letters in a column and capital letters in a row significantly differ from one another according to the ScottKnott test, at $5 \%$ significance. The letter "a" refers to the best result. * $\mathrm{SA}$ (Selective Accuracy) $=\sqrt{1-(1 / F C)}$, where $\mathrm{Fc}=$ calculated $\mathrm{F}$ value. $\mathrm{SA} \geq 0.9$ = very high; $\mathrm{SA}$ between 0.7 and $0.9=$ high; SA between 0.5 and $0.7=$ moderate; and $\mathrm{SA} \leq 0.5=$ low.

Foliar senescence was significantly affected only by the concentration of sucrose. Unlike in root formation, addition of sucrose at the maximum concentration $\left(30 \mathrm{~g} \cdot \mathrm{L}^{-1}\right)$ produced the best results (Table 3), that is, the lowest senescence average. It is possible that the presence of an external source of carbohydrates in the medium inhibited chlorophyll synthesis, therefore reducing the photosynthetic capacity of the shoots and increasing the number of senescing leaves.

In a previous study that explored the micropropagation of papaya (Carica papaya) cultivars in the absence of sucrose, the leaves of the shoots also presented chlorosis, indicating the need to add sucrose to the in vitro culture medium during rhizogenesis (SCHMILDT et al., 2007). This situation generally occurs because the formation of roots requires energy from photosynthesis or from another source.

An external source of carbohydrates is generally required for in vitro rhizogenesis, and the addition of sucrose to the culture medium at concentrations lower than $20 \mathrm{~g} \cdot \mathrm{L}^{-1}$ may lead to widespread chlorosis in the culture (GRATTAPAGLIA; MACHADO, 1998). Higher concentrations of sucrose in the nutritive medium are associated with higher concentrations of carbohydrates (or storage material) in the foliar tissue. Consequently, the leaves may remain attached to the plants for longer periods (CALVETE et al., 2002).

None of the tested factors had a significant effect on the number of roots; the conditions produced a poor average of only 1.04 roots per plantlet. By comparison, in papaya (C. papaya) cultivars, the addition of 0,15 , and $30 \mathrm{~g} \cdot \mathrm{L}^{-1}$ sucrose produced an average 3.35, 2.87, and 2.75 roots per plantlet, respectively, after 35 days of culture on MS nutritive medium (SCHMILDT et al., 2007).

Differences in the ability to form secondary roots have been attributed to differences in the auxin metabolism, which involves the conjugation of IBA with its inhibitors, as well as to differences in auxin transport and absorption (LUDWIG-MULLER et al., 2005).

The interaction between sucrose and IBA had a significant effect on root length $(p=0.0061)$ (Table 2). The absence of both factors produced the best result: an average root length exceeding $3 \mathrm{~cm}$. This value is close to that observed during the in vitro rhizogenesis of apple (Malus pumila) rootstocks on MS/2 nutritive medium combined with vermiculite, supplemented with sucrose and 1 $\mathrm{mg} \cdot \mathrm{L}^{-1}$ indole-3-acetic acid, which produced an average root length of $3.4 \mathrm{~cm}$ (VIEIRA et al., 2007).

In a study of the in vitro rhizogenesis of strawberries (Fragaria $\mathrm{x}$ ananassa) on MS medium in the absence of auxin, higher levels of sucrose resulted in higher root biomass. The presence of sucrose appeared to help more abundant and longer root growth. No root formation was observed in the absence of this external source of carbohydrates (CALVETE et al., 2002). 
Table 3. Mean survival percentage, number of leaves, and percentage of leaves with senescence symptoms in Peltophorum dubium (Sprengel) Taubert plantlets obtained from the in vitro rhizogenesis stage, on half-strength Woody Plant Medium (WPM/2), according to the presence or absence of indole-3-butyric acid (IBA), different sucrose concentrations, and the presence or absence of agar, after 56 days of in vitro acclimatization in a substrate consisting of pine bark, a correction for soil acidity, mineral fertilizers, and vermiculite $(1: 1, \mathrm{v} / \mathrm{v})$.

Tabela 3. Médias de porcentagem de sobrevivência, número de folhas e porcentagem de folhas com sinais de senescência em mudas de canafístula [Peltophorum dubium (Sprengel) Taubert] oriundas da fase de enraizamento in vitro, em meio nutritivo 'Wood Plant Medium' (WPM) cuja concentração de sais foi reduzida à metade (WPM/2), em função dos tratamentos que consistiram de combinações entre ausência ou presença de ácido 3-indolbutírico (AIB), diferentes concentrações de sacarose e da ausência ou presença de ágar, após 56 dias de aclimatização in vitro em substrato à base de casca de pinus, corretivo de acidez, fertilizantes minerais, e vermiculita $(1: 1, \mathrm{v} / \mathrm{v})$.

\begin{tabular}{lcccccc}
\hline Treatment number & IBA $(\boldsymbol{\mu M})$ & Sucrose $\left(\mathbf{g ~ L}^{-1}\right)$ & Agar $\left(\mathbf{g ~ ~ ^ { - 1 }}\right)$ & Survival $(\%)$ & Number of leaves & Senescence (\%) \\
\hline 1 & 0 & 0 & 0 & $59.37 \mathrm{~b}$ & $4.80 \mathrm{a}$ & $24.18 \mathrm{~b}$ \\
2 & 0 & 0 & 7 & $77.70 \mathrm{a}$ & $5.18 \mathrm{a}$ & $18.37 \mathrm{a}$ \\
3 & 0 & 15 & 0 & $87.50 \mathrm{a}$ & $5.00 \mathrm{a}$ & $28.44 \mathrm{~b}$ \\
4 & 0 & 15 & 7 & $57.50 \mathrm{~b}$ & $3.70 \mathrm{~b}$ & $25.26 \mathrm{~b}$ \\
5 & 0 & 30 & 0 & $79.17 \mathrm{a}$ & $4.08 \mathrm{~b}$ & $31.20 \mathrm{~b}$ \\
6 & 0 & 30 & 7 & $75.00 \mathrm{a}$ & $4.09 \mathrm{~b}$ & $32.73 \mathrm{~b}$ \\
7 & 10 & 0 & 0 & $9.37 \mathrm{~d}$ & $1.06 \mathrm{c}$ & $22.08 \mathrm{a}$ \\
8 & 10 & 0 & 7 & $37.50 \mathrm{c}$ & $2.21 \mathrm{c}$ & $17.16 \mathrm{a}$ \\
9 & 10 & 15 & 0 & $25.00 \mathrm{~d}$ & $1.17 \mathrm{c}$ & $16.12 \mathrm{a}$ \\
10 & 10 & 15 & 7 & $48.00 \mathrm{c}$ & $3.32 \mathrm{~b}$ & $29.81 \mathrm{~b}$ \\
12 & 10 & 30 & 7 & $56.25 \mathrm{~b}$ & $3.03 \mathrm{~b}$ & $20.37 \mathrm{a}$ \\
\hline Mean & & & 58.60 & 3.67 & 23.60 \\
AS $^{* *}$ & & & 0.96 & 0.95 & 0.74 \\
\hline
\end{tabular}

* Means followed by different lowercase letters in a column significantly differ from one another according to the Scott-Knott test, at $5 \%$ significance. The letter "a" refers to the best result. ** $S A$ (Selective Accuracy) $=\sqrt{1-(1 / F C)}$, where $\mathrm{Fc}=$ calculated $\mathrm{F}$ value. $S A \geq 0.9=$ very high; SA between 0.7 and $0.9=$ high; $S A$ between 0.5 and $0.7=$ moderate; and $S A \leq 0.5=$ low.

This finding indicates that when plants are cultivated in vitro, they require supplemental energy sources as well as plant regulators during the root formation stage, to an extent that depends both on their genotype and on the species.

\section{Use of sucrose in media}

It is interesting that sucrose is not required for rhizogenesis nor to produce a good-quality radicular system in micropropagation assays; because not adding sucrose to the nutritive medium not only reduces the likelihood of microbial contamination but also improves the physiological characteristics of the plants (DAMIANI; SCHUCH, 2009). In addition, the transition from the heterotrophic to the autotrophic medium is one of the most critical steps in the micropropagation of most plant species, and high survival rates obtained for acclimatized plants depend on the correct treatment during the process of transition of the plants from in vitro to ex vitro conditions (CALVETE et al., 2002). Optimal conditions during transition may be achieved by reducing salt concentrations and adding external carbon sources to the nutritive medium.

Plants cultivated in sterile media may be grouped into two classes according to their photosynthetic capacity. The first class includes heterotrophic or mixotrophic plants, which form leaves with no photosynthetic capacity when grown in sucrose-containing media. The second class includes plants that are adapted to in vitro autotrophic conditions and that, despite the artificial growth conditions, can achieve a considerable photosynthetic rate (GROUT, 1988).

P. dubium appears to fall into the latter category. Nevertheless, further detailed studies are necessary to confirm the photosynthetic capacity of the micro propagated plantlets. Photosynthesis certainly occurred, as root formation occurred even when no sucrose was added to the nutritive medium, a process that must have required energy from photosynthesis because there was no other external source of carbon.

\section{In vitro acclimatization}

The in vitro conditions significantly affected all the variables that were evaluated: survival rates $(p=$ $0.000)$, number of leaves $(p=0.000)$, and number of leaves showing senescence symptoms $(p=0.0149)$. Growth of plantlets was also significantly affected by the number of cultivation days $(p=0.000)$. 

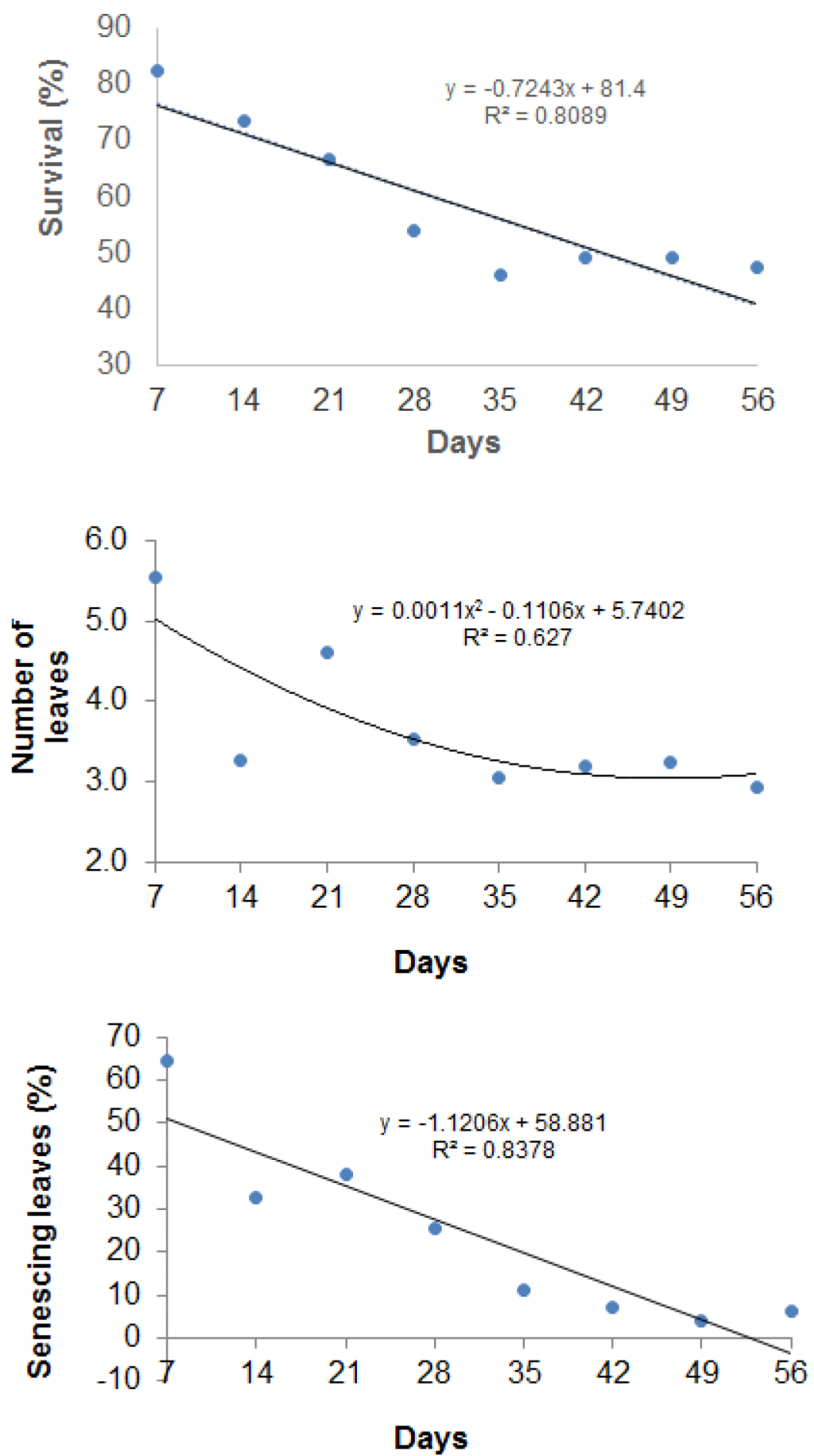

Figure 2. Mean survival rates (\%), number of leaves, and senescing leaves (\%) on Peltophorum dubium (Sprengel) Taubert plantlets with roots, according to the number of cultivation days, regardless of the presence or absence of indole-3-butyric acid (IBA), sucrose concentrations $\left(0,15\right.$, or $\left.30 \mathrm{~g} \cdot \mathrm{L}^{-1}\right)$, and the presence or absence of agar ( 0 or $7 \mathrm{~g} \cdot \mathrm{L}^{-1}$ ) on half-strength Woody Plant Medium (WPM/2) to which was added $30 \mathrm{~cm}^{3}$ vermiculite, during the in vitro acclimatization stage in a substrate consisting of pine bark, correction of soil acidity, mineral fertilizers, and vermiculite $(1: 1, \mathrm{v} / \mathrm{v})$.

Figura 2. Médias de sobrevivência (\%), número de folhas e folhas com senescência (\%) em mudas micropropagadas de canafístula [Peltophorum dubium (Sprengel) Taubert] em função dos dias de cultivo, enraizadas independentemente da ausência ou presença de ácido 3-indolbutírico (AIB), de diferentes concentrações de sacarose $\left(0,15\right.$ ou $\left.30 \mathrm{~g} \mathrm{~L}^{-1}\right)$ e da ausência ou presença de ágar ( 0 ou $\left.7 \mathrm{~g} \mathrm{~L}^{-1}\right)$, em meio nutritivo 'Wood Plant Medium' (WPM) cuja concentração de sais foi reduzida à metade (WPM/2), combinado com $30 \mathrm{~cm} 3$ de vermiculita, durante a fase de aclimatização in vitro em substrato à base de casca de pinus, corretivo de acidez, fertilizantes minerais, e vermiculita $(1: 1, \mathrm{v} / \mathrm{v})$.

The best results for all analyzed variables was achieved by not adding any sucrose or auxin, only the jellifying agent that was added to the nutritive medium combined with vermiculite (Table 3, treatment 2), corroborating the results obtained during in vitro rhizogenesis. This treatment produced 
Reinige et al. - Rizogênese e aclimatização in vitro de brotações

de canafístula: efeito do ágar em meio WPM/2 com vermiculita

the highest average survival rates (above 70\%) and number of leaves (more than 5 ) and the lowest percentage of foliar senescence (below 20\%).

In general, adding substances to the nutritive medium, including auxin, reduced average survival rates and produced plantlets that significantly differed from the treatments to which no IBA was added, with the lowest number of leaves. However, in some cases, these treatments did not produce significantly different effects on senescence than did treatment 2 , which combined the best results for all evaluated variables.

During the acclimatization period, survival and senescence rates decreased over time (Fig. 2). By the end of the acclimatization period, approximately $50 \%$ of the micropropagated plantlets had survived and they no longer showed senescence symptoms.

Presumably, the leaves that were senescing at the beginning of the treatment fell off in the course of the study and were gradually replaced by newly formed leaves. The number of leaves was stable from the $30^{\text {th }}$ day of the acclimatization period onward, with a slight tendency to increase. The surviving plants were most likely those that formed secondary roots during the in vitro rhizogenesis stage, since these organs are responsible for the absorption of water and nutrients required for plant sustenance.

The decreased plant survival rates that we observed are very common for this cultivation stage, since plant survival, growth, and productivity are intimately associated with the aerial environment through processes such as energy exchange, loss of water vapor in transpiration, and the assimilation of carbon dioxide during photosynthesis (PUROHIT et al., 2002). Water vapor exchange rate is severely altered on changing plants transition from in vitro to ex vitro conditions, a transition that alters the availability of energy; the transpiration rate of the leaves; and, consequently, the physiology of the plant as whole.

\section{CONCLUSION}

Sucrose and IBA are dispensable for the micropropagation of $P$. dubium, and a higher quality radicular system develops when half-strength Woody Plant Medium (WPM/2) nutritive medium is used, combined with $30 \mathrm{~cm}^{3}$ vermiculite and $7 \mathrm{~g} \cdot \mathrm{L}^{-1}$ agar. The shoots produced under these conditions present a well-developed radicular system that enables them to survive the in vitro acclimatization process.

\section{ACKNOWLEDGMENTS}

We are grateful to the Brazilian National Council for Scientific and Technological Development (CNPq) for granting the fellowships that supported this work.

\section{REFERENCES}

BASSAN, J. S.; REINIGER, L. R. S. ; ROCHA, B. H. G. ; SEVERO, C. R. P. ; FLORES, A. V. Oxidação fenólica, tipo de explante e meios de cultura no estabelecimento in vitro de canafístula (Peltophorum dubium (Spreng.) Taub.). Ciência Florestal, Santa Maria, v. 16, n. 4, p. 381-390, 2006. Disponível em: < http://redalyc.uaemex. $\underline{\mathrm{mx} / \mathrm{redalyc} / \mathrm{pdf} / 534 / 53416403 . \mathrm{pdf}}>$. Acesso em: 04 jun. 2012.

BRACHTVOGEL, E. L.; MALAVASI, U. C. Volume do recipiente, adubação e sua forma de mistura ao substrato no crescimento inicial de Peltophorum dubium (Sprengel) Taubert em viveiro. Revista Árvore, Viçosa, v. 34, n. 2, p. 223-232, 2010. Disponível em: < http://www.scielo.br/scielo.php?script=sci arttext\&pid=S0100-

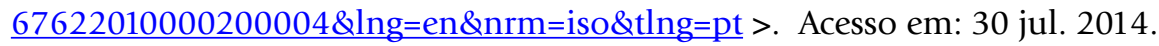

CALVETE, E. O.; KÄMPF, A. N.; SUZIN, M. Concentração de sacarose no enraizamento in vitro de morangueiro. Horticultura Brasileira, Brasília, v. 20, n. 2, p. 186-191, 2002. Disponível em: <http://www.scielo.br/scielo. php?script=sci arttext\&pid=S0102-05362002000200014\&lng=en\&nrm=iso\&tlng=pt $>$. Acesso em: 30 jul. 2014. 
CURTI, A. R.; REINIGER, L. R. S.; PAIM, A. F.; NAVROSKI, M. C.; GOLLE, D. P.; LEON, E. A. B. Efeito de BAP, isolado ou em combinação com outras citocininas, na multiplicação in vitro de Peltophorum dubium (Sprengel) Taubert. In: CONGRESSO DE INICIAÇÃO CIENTÍFICA E PÓS- GRADUAÇÃO DO SUL DO BRASIL, 2010, Florianópolis. Resumos... Florianópolis: CICPG, 2010.

CURTI, A. R.; REINIGER, L. R. S.; PAIM, A. F.; NAVROSKI, M. C.; SOMAVILLA, I. Efeito de citocininas na multiplicação in vitro de Peltophorum dubium (Sprengel) Taubert. In: SIMPÓSIO BRASILEIRO DE PÓSGRADUAÇÃO EM CIÊNCIAS FLORESTAIS, 2010, Rio de Janeiro. Anais... Rio de Janeiro, 2010.

CURTI, A. R.; REINIGER, L. R. S. Formação in vitro de raízes em canafístula: o efeito de diferentes meios de cultivo. Ciência Rural, Santa Maria, v. 44, n. 2, p. 314-320, 2014. Disponível em: <http://www.scielo.br/ scielo.php?script=sci arttext\&pid=S0103-84782014000200019\&lng=pt\&nrm=iso\&tlng=pt $>$. Acesso em: 30 jul. 2014.

DAMIANI, C. R.; SCHUCH, M. W. Diferentes substratos e ambientes no enraizamento in vitro de mirtilo. Ciência Rural, Santa Maria, v. 39, n. 2, p. 563-566, 2009. Disponível em: <http://www.scielo.br/scielo. php?script=sci arttext\&pid=S0103-84782009000200040\&lng=pt\&nrm=iso\&tlng=pt $>$. Acesso em: 30 jul. 2014 .

FERREIRA, D. F. Sistemas de análise estatística para dados balanceados. Lavras: UFLA/ DEX/SISVAR, 2000. $145 \mathrm{p}$.

FLÔRES, A. V.; REINIGER, L. R. S.; CURTI, A. R.; PAIM, A.; BASSAN, J. S.; CUNHA, A. C. M. C. M. Estabelecimento in vitro de Peltophorum dubium (Spreng.) Taub. em função das concentrações do meio MS. Cerne, Lavras, v. 17, n. 4, p. 549-553, 2011. Disponível em: <http://www.dcf.ufla.br/cerne/administracao/publicacoes/ m598v17n4o14.pdf >. Acesso em: 26 fev. 2015.

GRATTAPAGLIA, D.; MACHADO, M. A. Micropropagação. In: TORRES, A. C.; CALDAS, L. S.; BUSO, J. A. (Ed.). Cultura de tecidos e transformação genética de plantas. Brasília: Embrapa, 1998, v. 1., p. 183-260.

GROUT, B. W. W. Photosynthesis of regenerated plantlets in vitro, and stress of transplanting. Acta Horticulturae, Wageningen, n. 230, p. 129-135, 1988.

LLOYD, G.; MCCOWN, B. Commercially-feasible micropropagation of mountain laurel, Kalmia latifolia, by use of shoot-tip culture. Combined Proceedings International Plant Propagators Society, Seattle, v. 30, p. 421-427, 1980.

LORENZI, H. Árvores brasileiras: manual de identificação e cultivo de plantas arbóreas nativas do Brasil. Nova Odessa: Plantarum, 1992. 352 p.

LUDWIG-MULLER, J.; VERTOCNIK A.; TOWN, C. D. Analysis of indole-3-butyric acid-induced adventitious root formation on Arabidopsis stem segments. Journal of Experimental Botany, Oxford, v. 56, n. 418, p. 2095-2105, 2005. Disponível em: <http://jxb.oxfordjournals.org/content/56/418/2095.long>. Acesso em: 30 jul. 2014.

MURASHIGE, T.; SKOOG, F. A revised medium for rapid growth and bio-assays with tobacco tissue cultures. Physiologia Plantarum, Copenhagen, v. 15, n. 1, p. 437-496, 1962.

NAKAGAWA, J.; MORI, E. S.; PINTO, C. S.; FERNANDES, K. H. P.; SEKI, M. S.; MENEGHETTI, R. A. Maturação e secagem de sementes de Peltophorum dubium (Spreng.) Taubert (canafístula). Revista Árvore, Viçosa, v. 34, n. 1, p. 49-56, 2010. Disponível em: <http://www.scielo.br/scielo.php?script=sci arttext\&pid=S0100-

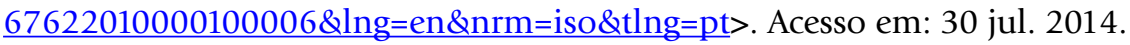


Reinige et al. - Rizogênese e aclimatização in vitro de brotações

de canafístula: efeito do ágar em meio WPM/2 com vermiculita

OLIVEIRA, L. S.; DIAS, P. C.; BRONDANI, G. E. Micropropagação de espécies florestais brasileiras. Pesquisa Florestal Brasileira, Colombo, v. 33, n. 76, p. 445-460, 2013. Disponível em: <http://pfb.cnpf.embrapa.br/ pfb/index.php/pfb/article/view/481>. Acesso em: 30 jul. 2014.

PEREZ, S. C. J. G. A.; FANTI, S. C.; CASALI, C. A. Influência do armazenamento, substrato, envelhecimento precoce e profundidade de semeadura na germinação de canafístula. Bragantia, Campinas, v. 58, n. 1, p. 57-68, 1999. Disponível em: <http://www.scielo.br/scielo.php?script=sci_arttext\&pid=S0006-

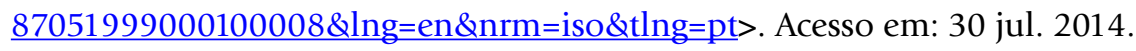

POLETTO, I.; CECONI, D. E.; HOPPE, J. M.; SANTIN, D.; MARTINS, F. B.; SCHUMACHER, M. V. Uso de diferentes qualidades de turfa para produção de mudas de canafístula (Peltophorum dubium (Sprengel) Taubert). Revista Brasileira de Agroecologia, Pelotas, v. 2, n. 1, p. 1122-1125, 2007. Disponível em: <http:// www.aba-agroecologia.org.br/revistas/index.php/rbagroecologia/article/view/6496>. Acesso em: 30 jul. 2014.

PORTELA, R. C. Q.; SILVA, I. L.; PINÃ-RODRIGUES, F. C. M. Crescimento inicial de mudas de Clitoria fairchildiana Howard e Peltophorum dubium (Sprengel) Taub. em diferentes condições de sombreamento. Ciência Florestal, Santa Maria, v. 11, n. 2, p. 163-170, 2001. Disponível em: <http://cascavel.ufsm.br/revistas/ ojs-2.2.2/index.php/cienciaflorestal/article/view/1664>. Acesso em: 30 jul. 2014.

PUROHIT, V. K.; TAMTA, S.; CHANDRA, S.; VYAS, P.; PALNI, L. M.; NANDI, S. K. In vitro multiplication of Quercus leucotrichophora and Q. glauca: Important Himalayan oaks. Plant Cell, Tissue and Organ Culture, Wageningen, v. 69, n. 2, p. 121-133, 2002. Disponível em: <http://link.springer.com/article/10.1023/ A\%3A1015296713243>. Acesso em: 30 jul. 2014.

REZENDE, M. D. V; DUARTE, J. B. Precisão e controle de qualidade em experimentos de avaliação de cultivares. Pesquisa Agropecuária Tropical, Goiânia, v. 37, n. 3, p. 182-194, 2007. Disponível em: <http://www.revistas. ufg.br/index.php/pat/article/viewFile/1867/1773>. Acesso em: 26 fev. 2015.

SCHMILDT, E. R.; AMARAL, J. A. T.; SCHMILDT, O. Sacarose na fase de enraizamento in vitro de mamoeiro 'Tainung'. Scientia Agraria, Curitiba, v. 8, n. 1, p. 25-31, 2007. Disponível em: <http://ojs.c3sl.ufpr.br/ojs2/ index.php/agraria/issue/view/108>. Acesso em: 30 jul. 2014.

SILVA, P. H. M.; WICHERT, M. C. P.; GONÇALVES, J. L. M. Indicadores estatísticos sobre viveiros florestais no Brasil. Piracicaba: IPEF, 2008. Disponível em: <http://www.ipef.br/silvicultura/indicadores.asp $>$. Acesso em: 14 jan. 2014.

VIEIRA, R. L.; LEITE, G. B.; WAMSER, A. F. Efeito de substratos porosos no enraizamento in vitro do porta-enxerto de macieira M-9 (Malus pumilla). Revista Brasileira de Fruticultura, Jaboticabal, v. 29, n. 1, p. 128-132, 2007. Disponível em: <http://www.scielo.br/scielo.php?script=sci_issuetoc\&pid=0100294520070001\&lng=en\&nrm=iso $>$. Acesso em: 30 jul. 2014.

XAVIER A.; WENDLING L.; SILVA, R. L. Silvicultura clonal: princípios e técnicas. 2.ed. Viçosa: UFV, 2013. 279 p.

Recebido em 23/04/2015

Aceito para publicação em 02/02/2016 